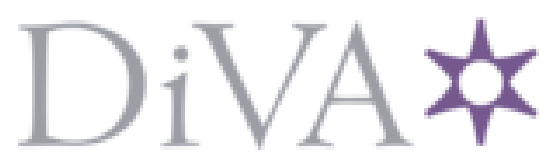

http://www.diva-portal.org

\title{
Postprint
}

This is the accepted version of a paper published in Educational action research. This paper has been peer-reviewed but does not include the final publisher proof-corrections or journal pagination.

Citation for the original published paper (version of record):

Gillberg, C. (2011)

A narrative of an action research study in preschool: choice points and their implications for professional and organisational development.

Educational action research, 19(2): 137-152

http://dx.doi.org/10.1080/09650792.2011.569187

Access to the published version may require subscription.

N.B. When citing this work, cite the original published paper.

This is an Author's Accepted Manuscript of an article published in Educational action research: "A narrative of an action research study in preschool: choice points and their implications for professional and organisational development", Claudia Gillberg, Educational Action Research, Vol. 19, Iss. 2, 2011. Published online: 08 Jun 2011, copyright Taylor \& Francis, available online at: http:// www.tandfonline.com/10.1080/09650792.2011.569187.

Permanent link to this version:

http://urn.kb.se/resolve?urn=urn:nbn:se:hj:diva-15301 


\section{A narrative of an action research study in preschool: choice points and their implications for professional and organisational development}

\section{Background}

Swedish preschool's societal and educational mission is still somewhat ambiguous today (Persson \& Tallberg-Broman 2002; Vallberg-Roth 2001). Since 1998 a national curriculum for Swedish preschools has been in operation (Lpfö 98 1998). Values such as gender equity are strongly emphasised, meaning that preschool teachers do not have a choice but to practise gender equity pursuant to Lpfö 98. The development of pedagogic methods that may boost gender equity in preschool is one of several educational policies that preschool teachers ought to translate into their professional practice according to educational state policy.

The organisational context of the preschool teachers in this study was a small municipality in southern Sweden. Municipalities in general do not necessarily operate on principles of participative democracy (Pincus 2002). While Quennerstedt's (2006) research illustrates that municipal politicians respect teachers' professional tasks such as interpreting curriculum and educational policy, Pincus (2002) maintains there is no broad acceptance of the qualitative aspect of gender equity in municipalities. Focus on preschool teachers' agency is therefore of particular interest in order to understand collective and individual processes in the light of organisational and professional limitations and ambiguities (Dahle 2008; Etzioni 1969; Witz 1992). Tallberg-Broman's (1991) research on the history of preschool teachers in outlines the specific problems of the Swedish preschool. Her findings show that preschool is a gendered workplace suffused with colliding ideas about the child as a precious plant, coming from Germany (Fröbel 1826) and the idea of preschool being a means to an end, facilitating labour market participation for mothers. As for the implications regarding a women-dominated workplace such as preschool, Tallberg-Broman (1991) points out that care, a key element in the preschool teachers' profession, connotes in terms of giving love and providing a family home-like atmosphere for the child. This means, to some extent also today, that preschool teachers are not really supposed to fight for professional status and acceptable salaries for their work. Tallberg-Broman explains how, historically speaking, working as a preschool teacher was supposed to be so rewarding that to claim an acceptable salary and professional status would have been regarded as preposterous. This is but one of many aspects, and possibly explanations, as to the relatively low societal status of preschool teachers to this day.

The concept of agency has been rarely applied to preschool teachers. Furthermore, gender equity, the preschool teachers' object of knowledge in this study, is regarded as controversial in educational settings and often criticised for its ideological origins (Berge \& Ve 2000). It must be underlined, however, that the preschool teachers' object of knowledge in this study was nothing they could choose to omit due to the fact that gender equity is indeed part of the current educational state policy. In other words, all they did attempt to do was to adhere to policy.

During 2006, the preschool teachers and I were part of an official project funded by the Swedish Ministry of Research and Education. When the official project came to an end, the preschool teachers in my group expressed a wish to continue with their knowledge process. $I$ identified this as a salient opportunity to initiate a feminist action research project. The starting point was ideal insofar as the preschool teachers themselves had asked to be part of 
a project in which they, the so-called practitioners, would be regarded as agents, rather than objectified informants (cf. Campbell \& Groundwater-Smith 2007; Reid 2004).

It needs to be underlined, however, that my research interest and the preschool teachers' knowledge interest did not converge entirely. Mainly this was due to the varying natures of the tasks inherent in our different practices: mine was to produce a doctoral thesis while the preschool teachers' task was to develop their pedagogic methods regarding the concept of gender equity. The preschool teachers in this study interpreted and identified this particular policy as necessary to develop professionally, as they did not consider their practices in compliance either with Swedish educational policy or school law on this particular point.

In this article, while drawing on some of the results of my doctoral thesis, I mainly focus on the choice points the preschool teachers themselves described as most significant for their possibilities to achieve change. The choice points are regarded as reflections and actions resulting from reflections. I interweave these choice points with thoughts on the role I had, or was given, by the preschool teachers in their project.

\section{Further structure of and focus in this article}

I will first present some of my theoretical and philosophical underpinnings. Feminist Action Research and pragmatism are then presented as mutually beneficiary in terms of transformation and knowledge. I then give some empirical examples of how the preschool teachers succeeded in some of their change and knowledge work. By concentrating on some so-called choice points, the empirical and analytical narrative emerges, while my position and role as an action researcher in this project is problematised throughout the narrative. The article ends with a discussion of preschool teachers professional and organisational development, and a reflection on my own learning.

\section{Theoretical and philosophical underpinnings}

I chose to draw on feminist pragmatism based on my understanding and respect for Dewey's pragmatist thought in which theorising is regarded as an integral part of people's interaction with their environment (Seigfried 2002). The subsequent discovery of some of Dewey's professed sources of inspirations, e.g. Jane Addams and her Hull House project further fuelled my interest in feminist pragmatism (Minnich 2002, 2005). Women philosophers in early pragmatism filled a particular function by naming and expressing women's experience, transforming it into social activism, and subsequently carrying this knowledge into the academy. One hundred years ago, women's experiences had hardly made an impression in and on public life, and certainly not in the academic world. These women needed to become conversant with their new academic and political engagement and found that pragmatism resonated well with their needs for social change. Seigfried (2002) maintains that Dewey's philosophy in particular

Is not part of the impoverished tradition of discourse that feminists criticize. It is not among those philosophies that can talk about the power of reason but not about the power of empathy. (Seigfried 2002, 47)

Two aspects of pragmatist philosophy were considered particularly empowering:

(1) The principle that theory is generated from experience and that theory is accountable to practice (Seigfried 2002), which made it possible for women to trust their own experience as a starting point for reflection; and

(2) The principle that 'the purpose of inquiry into experience was not to replicate it, but to interrogate problematic situations in order to satisfactorily resolve them." (Seigfried 2002, 51). 
These two principles seemed applicable to the preschool teachers' situation, as they were challenged to trust their professional experience of being preschool teachers, and also, to interrogate the problematic situation of having to translate educational policy into their social and pedagogic practices.

\section{Knowledge and social justice as theoretical and pragmatist concepts in this study}

Our knowledge of the world is given to us in the modes by which we enter into relations with the object of knowledge (Smith 1990) and the object of our knowledge 'is or originates in the co-ordering of activities among "subjects"' (p. 11). To know the world of our experience and to see what is produced or accomplished in people's ongoing and co-ordered practices in definite places and time constitutes the relations between the subject and the object (Smith 1990, 199). A point of departure and a fundamental assumption here are that 'women's experience' exists due to the specific locations women find themselves in. Preschool, which is almost entirely borne by women, is such a gendered place. The characteristics ascribed to childcare as a gendered action, not least in a historical and contemporary perspective (e.g. educational policy), the context of preschool outlined here earlier and notions of what gender equity in preschool is or ought to be, constitute 'women's experience'. Smith (1990) refers to these kinds of locale as 'practices of knowing' and is particularly interested in

The objectified forms of institutional organization ... that become visible at the point of rupture, but at the same time are practices in which we participate, that we know from the inside, and that shape the practices through which we have sought to establish women's interests and experience on the terrain of ruling (Smith 1990, 11).

From the outset of this action research project, it was clear to me, and the preschool teachers, that I required a methodology that would focus the preschool teachers' action and that would somehow give me the opportunity to be part of the project (table 1). Active engagement in their own practices and challenging their own preconceptions of what needed to be done in their organisational settings were some of the preschool teachers' voiced ambitions with this project. They had invited me into this project so that I should challenge them with questions about their practices and their underlying intentions. I was thus given the role of the outsider, looking in.

\section{Feminist action research - methodology and applied method research}

A decisive distinction from more traditional research is a preposition here, which marks the difference between doing research on and doing research with (Reid 2004). Reid also states that feminist action research 'is a promising, though under-developed, research approach for advancing social justice agendas'. How does feminist enquiry contribute to the philosophy and theory of education? Notions of social justice can cast a light on how research is conceptualised and conducted (Reid 2004). In short, feminist action research is 'a conceptual and methodological research framework that is fundamentally about exploring and pursuing opportunities for social justice' (Reid 2004, 3). As such, feminist action research is self-consciously value-driven. It advocates methods of data collection and analysis that are grounded in the context of the community and contribute something of value to the community in which the research is conducted (Reid 2004).

My doctoral thesis was carried out on the assumption that women have traditionally been excluded from producing dominant forms of knowledge (Dahle 2008; Minnich 2005; Smith 1990). Some feminists claim that the mothering/nurturing intention inherent in policy is nowadays almost hidden due to projects such as gender equity in preschool, in other words, they regard such projects as counter-productive. So-called femocrats (Mazur 2006) may well lead preschool teachers to believe that they indeed are professionals in whose professional power it lies to implement gender equity. Femocrats thereby ignore the 
meaning of being situated in a strongly gendered workplace. Preschool teachers are caught in a web of contradictions in which it is hard to find time and space for reflection, let alone learning (Griffiths 1998).

In consequence of this outline of my theoretical underpinnings and feminist action research, knowledge production is considered by way of subscribing to what Reid (2004) defines as the conceptual and methodological framework of feminist participatory action research:

\begin{abstract}
A critical understanding of women's multiple perspectives and works toward inclusion, participation, action, and social change while confronting the underlying assumptions the researcher brings into the research process. Feminist action researchers facilitate building knowledge to change the conditions of women's lives, both individually and collectively, while reconstructing conceptions of power so that power can be used in a responsible manner. (p. 7)
\end{abstract}

Again, my participation in the project was very much based on my awareness of the preschool teachers possibilities and limitations due to their organisational setting and the historically gendered nature of their profession. We discussed these points of departure frequently and recurrently over the course of the three project years, and there was general agreement on my role and that preschool is a fundamentally gendered workplace.

\title{
Design of the study
}

For action researchers it is crucial to identify their positions and intentions, preferably prior to embarking on a research project. This way, the power dimensions inherent in research can be rendered visible and research questions as well as analyses can be viewed by taking into account the researcher's bias. Feminist action researchers usually operate on the assumptions that issues of power need to be considered and addressed in every single aspect of a research study, not just a few aspects of it. Herr \& Anderson (2005) provide a more general overview of how possible positions and researchers' perspectives, the inherent criteria of validity and the contributions an action researcher intends to make. As Maguire (2005 in Herr \& Anderson) explains:

\footnotetext{
Doctoral researchers are asked to sort through their own multiple positions and identities, and those of collaborators. The difficult but necessary choice points of potentially transformative knowledge creation are mapped out and named for what they are: political decisions with power dimensions that the doctoral researcher must work through and publicly articulate. (in Herr \& Anderson 2005, xiii)
}

In this light, the following overview becomes relevant also for this study as I had to negotiate several choice points of so-called potentially transformative knowledge creations that are mentioned in Herr \& Anderson (2005). These choice points have everything to do with the researcher's position and underlying intentions. Therefore, I will discuss focus on these choice points in this article by letting the narrative of the project evolve around them.

\section{[Table 1 in here]}

As I have already pointed out earlier on in this article, my role was initially that of an outsider looking in (position 5, table 1). However, this role shifted over time. As the doctoral thesis began to draw to a close, I found myself increasingly in position 6 (table 1), which I did not feel too comfortable with at times. Therefore, I made sure to counterbalance position 6 by way of sharing my analyses with the preschool teachers. They had access to all my drafts and I frequently shared my thoughts with the whole group and would listen to the preschool teachers' comments and criticism. Once the project was terminated, I made attempts at initiating reciprocal collaboration (position 4, table 1), for instance by designing an action research course with and for preschool teachers, creating professional networks with and for preschool teachers as well as a number of other initiatives that we thought would promote 
preschool teachers' professional status, such as inviting municipal key persons to meetings, also after the project ended.

\section{Choice points for reflection and action}

Participants in a research study must be able to frame and formulate problems in their own practices (Reid 2004). The ethical and moral dimensions of this type of research become particularly evident as participants/practitioners are not regarded as informants (Griffiths 1998) but active and thinking agents who are not only capable but also important agents for change within their organisations and professional lives (McNiff \& Whitehead 2000). This way, feminist action research fulfils one of its most significant intentions, namely not to replicate and enhance the injustices that research has made itself guilty of by constructing women into objects that can be frozen in time. Furthermore, this type of research cannot afford to make assumptions about any participant to suit certain purposes (Griffiths 1998).

As Reid and Maguire basically say the same about potentially transformative choice points, I present a list of points that the preschool teachers themselves identified as particularly important for their professional development during the years of 2006 to 2008 . These choice points were dealt with in detail during this study. The preschool teachers themselves called these critical incidents their 'eight milestones':

- $\quad$ The project itself

- The slowly emergent decision to participate in the government funded project

- The author

- $\quad$ Funding for smaller pedagogic and professional development projects

- $\quad$ Emerging new pedagogical practices

- A study day at another preschool that had worked longer and more explicitly with gender equity in preschool as a pedagogic aspect

- Organisational changes in general and in particular

- $\quad$ Conceptualising and writing up a gender equity plan, which was a goal from the outset

\section{Detailed insight gathering}

These insight gatherings, a term I borrowed from Griffiths (1998), were directed by the needs and requirements of the preschool teachers and my own needs to form a better and more comprehensive understanding of the multiple processes at individual and collective levels of the project which was conducted from January 2006 to November 2008. All in all, nine preschool teachers participated in the project, although some were replaced by others in the course of time, due to part-time employments and other concerns of administrative nature. In addition to our project meetings I used:

- One-on-one interviews with the participating preschool teachers. The character of these interviews was rather that of a confidential conversation with regard to the project's meaningfulness, the preschool teachers' own involvement and level of commitment and, in some cases, very personal accounts of private lives in relation to gender equity. I regarded these interviews as of great value in terms of validation of my own role as a participating researcher and of the project as such. None of the preschool teachers expressed thoughts towards wanting to leave the project. Nor did they express thoughts as to the project's many organisational obstacles, as I had expected them to do.

- About 1,000 exchanges by e-mail in between project meetings. These e-mails served a variety of purposes: (a) information of ongoing processes and other issues concerning our project, (b) more or less instant feedback on project meetings (e.g. "I found our meeting today so very uplifting. Thanks, we really got things done"), (c) personal notes saying 'just dropping a line to wish you a lovely weekend', signalling concern for each 
others' wellbeing and creating a general mood of goodwill, and positive spirit of collaboration.

- 3 group interviews, i.e. one interview per child age group (the preschool was divided into three separate departments by age group of the children. One for the youngest ones aged $1-2$, one for the middle group children, aged $3-4$, and the department for the oldest children aged $5-6$ ).

- Three observations in total, spread out over three years and by specific demand of preschool teachers in regard to particular problems they thought needed attention and careful thought and discussion.

- Personal letters from some of the preschool teachers who were not as used to emailing as some of the others.

- $\quad$ One personal life story account by a preschool teacher who had been at the preschool for over thirty years. However, that account was never used for analysis for personal reasons.

- About twenty telephone calls of varying length.

- A total of 5 interviews and strategic meetings with the heads of the preschool. At one of the strategic meetings, two of the preschool teachers were present to clarify a number of practical and organisational matters and to validate what was being said.

These insight gatherings also rendered visible what Brydon-Miller refers to as

The complex nature of balancing individual and collective actions and the relationships of power and privilege, which inevitably frame these processes of decision-making. (Brydon-Miller 2008, 202)

In other words, the practitioners' collective and individual needs had to be carefully balanced and considered during all stages of this study. The many parallel processes of action, reflection, both at a collective and individual level, required sensitivity, an ability to listen, but also a preparedness to criticise in a way that would help the preschool teachers see their own practices and change projects. I was, after all, given the task of outsider (position 5, table 1), that was supposed to contribute to the preschool teachers' professional development as well as to the change they considered was required within their organisational setting in order to comply with current preschool policy.

\section{An analytical narrative based on choice points and their resulting actions}

The analytical narrative that I present here (McNiff in Clandinin 2007) is based on the preschool teachers' actions taken within the three-year study. These actions should be understood in light of the resistance experienced by the preschool teachers, mainly from their employer, but also, to some extent, from the children's parents. While the municipal employer exercised all manner of power to prevent the preschool teachers from actively engaging in organisational development by means of concentrating on a particular educational policy over a lengthy period of time (cf. Quennerstedt 2006), the preschool teachers were not deterred by the municipality's attitude. Here is one example of municipal resistance and the preschool teachers' actions. A municipal representative, mostly a person with the function roughly comparable to that of a head teacher, would ask the preschool teachers to submit a report on their progress. Such a request would typically be sent by email on a Friday afternoon with a deadline for the report to be handed in on the Monday. This posed problems for the preschool teachers, as they could not write up a report on a Friday afternoon when there is hardly any staff. Neither could a report be written up on a Monday morning, one of the busiest times for preschool teachers. The preschool teachers 
refused, however, to give their employer cause for complaint and formulated email messages that explained the nature of the project and the time-consuming efforts that were put into the project and, in fact, into report writing. However, they went on to explain, they needed to have control over their work hours in more meaningful ways than writing progress reports on a Friday afternoon, without prior notice. The preschool teachers would always conclude their explanatory emails to their employer by emphasising how much they would welcome dialogue and meetings with head teachers, principals, and others in municipal middle management. Lastly, they would issue invitations to information meetings about the project and give several alternatives regarding place, date and times. During the three years of this project, not once did a municipal representative show interest by replying to one of the preschool teachers' emails or personal telephone calls, and not once was there a professed interest in reading the many reports that were available at the preschool's premises. The preschool teachers often said that they would find such non-reactions from their employer crushing, were it not for their knowledge that their project was of significance. How did they know that, though? The preschool teachers pointed out that having an ally from the outside (cf. table 1, position 5) proved to be valuable to them in terms of being able to see themselves through the lens of another person. They also said the fact that I used the project to write a doctoral thesis on the basis of it, was sufficient evidence, for them, to realise that what they were trying to achieve could not possibly be devoid of meaning.

This example illustrates that choice points have implications for the practices of others'. In this case, the project as such, the preschool teachers' decision to participate in a statefunded project as well as my participation in it, proved to be powerful actions, (see also outsider/insider research, Herr \& Anderson 2005). There was an emergent, acute awareness of the potential implications of actions on the preschool teachers' part as they went ahead and initiated some minor tentative changes, for instance by trying get control over their time at work and how they thought it might be spent in the most meaningful way possible. Actions slowly acquired more functions than to develop social and pedagogical practices. The preschool teachers realised, over time, that actions could be used as a strategic means to reach a certain end. By questioning their limited scope for action, or what they experienced as a limited scope, they began to engage more and more with the organisational setting of preschool in terms of questioning their subordinate professional role in the municipality. Issues such as budget cuts for preschools were increasingly addressed.

The preschool teachers' pedagogical-practice actions were about developing methods they themselves considered adequate for offering young children access to all kinds of activities, beyond the activities' stereotypical connotation. The preschool teachers described this part of their project in terms of change within the organisation. A few examples here are the so-called choice methods (that have nothing to do with the choice points in this article) for small children to encourage them to choose to play with certain toys. The children are supposed to express what toys they really like to play with and not because they thought they had to play with certain toys in order to ascertain gender specific roles. These methods revealed much about the children's patterns in choosing and opened up for new ways of thinking even among the children. A Barbie doll did not have to be pretty and inactive, but could be used as a fire fighter driving one of the toy tractors, while Barbie's Ken stayed at home cooking dinner. The preschool teachers were astonished to find that minor rearrangements of furniture, toy boxes and such could lead to major changes in the children's and their own perceptions of what choices really were on offer.

An example for a social-practice action was the writing up of a gender equity plan for this particular preschool, which challenged the preschool teachers' innermost belief system. Dialogue-based learning took place at every one of our meetings. Gender equity in preschool was much discussed and often puzzled over. Knowledge production of, on and about gender equity, they realised, would not and could not occur in a linear, but rather circular, way. As our many meetings and one-on-one interviews revealed, no one in the group thought that gender equity could be learned and 'done' in a fashion resembling traditional subject matters. Gender equity was, early on in the process, recognised as a subject far too complex to limit to a given place and time. Interestingly, the group agreed 
rather quickly among themselves that any organisational development to do with gender equity would have to involve themselves and could not be limited to pedagogical methods for the children. The preschool teachers called this 'the inner journey', which I thought could be interpreted as a wish to become more reflective of their own gendered practices. Consequently, the object of knowledge was intertwined with the conditions for our shared learning processes in the project, meaning that the form aspect of this work was as important as the preschool teachers' subject matter gender equity to develop better pedagogic methods.

I had earlier mentioned, as yet another choice point, a study day that the preschool teachers planned. To this end, they intended to visit a preschool that had become known in the whole country, as a good example of how to work with issues of gender equity in preschool. Now, while a study day may sound harmless enough, it caused a storm in the preschool teachers' municipality due to the immense cost it would entail. Not only would the municipality have to hire stand-ins for the one or two days the preschool teachers' would be absent, but it would also mean costs for overtime they preschool teachers could claim for being away over night. The municipal employer, finally, said that the preschool teachers could not go on a study day and that the decision was final. This outraged the preschool teachers as they knew on good authority that other municipal employees were proactively sent away to attend courses or study days in order to develop professional skills or otherwise make a new, desired contribution to their workplace. In the case of the preschool teachers, professional skills development was traditionally limited to an activity that a head teacher would choose. They would then be informed of what activity was on the agenda, whether the preschool teacher found the activity useful or not. Failure to attend such an activity had to be substantiated for instance by means of a physician attesting to some illness or other. In short, study days were offered to the preschool teachers, they were just not based on the preschool teachers' own professional needs and requirements. Now that the preschool teachers voiced such needs and requirements, the municipality resorted to put a stop to it by claiming there was no budget for their plans. The many emails and telephone calls over the course of several months served as a rich source of reflections on new and necessary actions.

While the preschool teachers kept on developing their social and pedagogical methods, they had to address, simultaneously, issues of organisational limitations that they thought seriously curtailed them in their professional roles as preschool teachers. In the end, the preschool teachers learned how to apply for external funding by engaging my help to write an application to the local union for teachers and preschool teachers. The local union's representative dismissed the application the first two times. When asked why he had found the application lacking, he replied that he considered the application poorly written and lacking in purpose. It needs to be underlined here, that the application was read and proofread by my supervisor back then, who found it to be an excellently formulated application, with a clearly stated purpose and a modestly calculated budget to cover the expense of travel and the fee to the receiving preschool for providing material and guidance for a whole day. I asked the preschool teachers if they wanted me to take on a more active role by asking the union's representative what he wanted to read in the third application they intended to submit. The preschool teachers' asked me to go ahead. What I had to report back to the preschool teachers was that their application would be benignly looked upon in the future, and that they had important work to do. However, he wanted to teach the preschool teachers a lesson by not immediately granting them funding, as he thought they should first learn to acquire a more formally correct language. The application was submitted for the third time, and the preschool teachers were granted SEK 15000 . This is not a huge amount for nine preschool teachers to travel with, but they were very happy and relieved to have circumnavigated their own employers' decision not to fund them. Now they could contact their employer again and say that they had secured their own means for travelling to Stockholm and that they were of the firm intention of leaving. They gave two possible dates for their employer to choose from and said they would help find adequate stand-ins. Finally, the day came when the preschool teachers embarked on their study day, which turned out to be a huge success in terms of feelings of empowerment (others are trying to do the same as 
we, others struggle with the same questions as we, other experience the same organisational obstacles as we and they deal with it in inspirational ways, etc). The preschool teachers returned to their workplace, full of ideas for further improvements and new methods they wanted to try out. Yet, they were also filled with pride of their own achievements and could state that they themselves were not doing a bad job at all. The preschool teachers at the Stockholm preschool were impressed with their project, I was told.

One more empirical example here is the discovery I made, one day, when I chanced upon a preschool teacher in a tiny room filled with old toys, that were neatly lining some deep shelves. I leaned in the doorframe and had a little chat with the preschool teacher while she was sorting through something I did not pay any attention to at first, as I must have thought of them as toys to be stacked onto the shelves. We talked for about five minutes, yet she would not interrupt her activity of sorting. Finally, it dawned on me that what I saw were not dolls' clothes or toys, but dirty laundry. I then discovered that there was a washing machine crammed into the little room, underneath one of the shelves, and exclaimed "Goodness me, you're not doing the laundry for this place, are you?!". I received the following reply "Of course l'm doing the laundry. We even have scheduled our time so that none of us will have to waste too much precious time in here. I mean we need to spend our time at work with the children, not doing the laundry. But what are we supposed to do? The van that came around once or twice a week is a thing of the past. But yes, we did have a municipal laundry service for all school and preschools in this municipality."

We later found out that the laundry van still existed and served the primary and secondary schools in the municipalities. The preschools, on the other hand, were all equipped with washing machines instead.

Lastly, the preschool teachers engaged in writing up a gender equity plan for the preschool that could serve as a good example for other preschools in the same municipality. A lot of time and reflection went into this policy document, whose other function was to serve as a written evaluation of the project as a whole. Another intention with the gender equity plan was to use it as a document of principles, for instance in interviews with potential new employees. Staff meetings, the preschool teachers thought, should always relate to the gender equity plan and not consider it as yet another heavy duty item to be ticked of the list of "must do's". The gender equity plan once saved the municipality from being blacklisted by a state audit on the very point of gender equity in the municipalities' schools and preschools. Having been forewarned a couple of days prior to the audit, the municipal memory did come up with the preschool teachers in the project here presented. They received a telephone call from one of the area's principals. In the telephone call, the municipal representative expressed her despair at not being able to furnish evidence as to a gender equity plan in the entire municipality except for the "brilliant example" set by said preschool. The preschool teachers obliged and thought that they could use the occasion for future reference and also, to render themselves more visible within the overall municipal organisation.

\section{Some analytical thoughts with regard to choice points}

The choice points, or what the preschool teachers called their eight milestones, were of significance in several ways. Early on in the project, a choice point as such as earlier mentioned, the preschool teachers uttered astonishment at how much time it took them to agree on what to do to achieve change towards their desired policy goal gender equity. They soon found out that the last thing they had was time to do all the work they envisaged they would do. The preschool teachers' ensuing struggle to create time and space for the development of their organisational setting is noteworthy because

(i) The transformative aspects of knowledge processes over time were particularly discernible within the preschool. Collective and individual learning by means of reflection contributed to knowledge production. Actions were eventually perceived as meaningful by all preschool teachers involved. However, the transformative knowledge processes had their limits in so far as they did not quite reach the municipal employers 
at their various organisational levels. Dewey's transformative thoughts (Biesta \& Burbules 2003; Biesta 2006) were not in evidence outside the preschool due to the fact that no one within the municipal organisation would take notice of the preschool teachers' knowledge production, as I illustrated by giving an example earlier in this article. The only time the preschool teachers received due attention from their employer, was when the latter was faced with a government audit on gender equity in schools and preschools. This was, however, not the drastic change the preschool teachers wished to see as permeating their entire organisational setting. After all, the preschool teachers themselves had paid for the professional development by applying for external funding for a study day, and had to put themselves through rather a degrading process of applying and re-applying several times for said funding.

(ii) The organisational and professional implications of this study are that gendered workplaces such as preschool do not have a self-evident and recognised position within an organisation such as the municipality (Dahle 2008, Davies 1996; Quennerstedt 2006; Witz 1992). A strongly gendered workplace such as preschool is a complex issue; first of all, it needs to be established if and how preschool teachers are recognised as professionals by municipal politicians and policy makers (Mazur 2006; Quennerstedt 2006), as there were strong indications that the preschool teachers were not taken seriously as professionals. This can have a considerable impact on preschool teachers' possibilities to take hold of their professional core tasks and substantiate these from within. Conceptions of agency are potentially pivotal in the struggle for learning and space and time for reflection (Smith 1990). The organisational obstacles in terms of resistance from the municipal employer proved to be unexpectedly fierce. This resistance was unexpected because, after all, the preschool teacher merely engaged in what they are, by law, obligated to engage in: the translation of educational policy into adequate pedagogical and social practices at their workplace.

Preschool teachers need to address the ambiguous professional identity that is theirs. Their ambiguous professional identity can be explained by the historical and political conditions under which preschool emerged as a field of practice over the past 150 years, are strongly gendered (Berge \& Ve 2000). One of the core tasks in preschool is to provide very young children with a caring and home-like environment. This is often confused with parental care and love by municipal employers who, if not explicitly, ascribe a rather low professional value to preschool teachers. The washing machine in the little room in the preschool this study took place, may serve as a symbol of the confusion on part of the municipal employers as to the core task of preschool teachers. This stands in stark contrast to government policy (2006:75) in which the importance of preschool teachers is emphasised. However, educational policy is not free from ambiguities in their descriptions of parental care and professional care and how these are supposed to complement each other (Berge \& Ve 2000). The contradictory terms in which preschool teachers are supposed to complement parental care are merely one example to illustrate some of the ambiguities. It is unclear on which underlying assumptions such formulations came about. They are, however, strongly reminiscent of some of the political and ideological ideals that prevailed e.g. in the 1930s when Alva Myrdal proclaimed her social democratic visions of a Swedish model for childcare. The question to this day, then, is whether parents are, implicitly, considered inadequate as providers of care and proper education of their own children. Another question is whether preschool teachers are considered inadequate because preschool is essentially regarded as a place where children are unloaded so that their parents can pursue their professional careers. This is a rough outline of some of the problems preschool teachers will have to face as soon as they take charge of certain aspects of their professional practices, such as interpreting educational policy. The empirical narrative shows that municipal employers appeared to be confused by and hostile towards preschool teachers' professional endeavours for change. 
Municipalities are organisations that operate on different rationalities and professional points of reference than do preschool teachers within their workplace. This is problematic for several reasons, but one is particularly pressing to resolve: both preschool teachers and municipal employer are part of one and the same organisation, which comprises many different professions. In applying feminist theories of organisation and profession, it became apparent that the ambiguous character of preschool teachers' profession is not entirely random (cf. Dahle 2008, Davies 1996) and is often to do with the value that is ascribed to a certain organisational setting. It is well known, that professions with an emphasis on care (nursing, social workers, primary school teachers, physiotherapists, preschool teachers etc) are women-dominated (Dahle 2008; Davies 1996; Witz 1992). On the whole, they do not have a specifically high status. Yet another indicator for low status is that organisations such a municipalities somehow never seem to have the right budgetary means to allocate to this type of workplace (Quennerstedt 2006). The preschool in this study was not regarded as an asset but as an expense, a drain on an already strained municipal budget. It is all the more noteworthy that the preschool teachers in this project did not shy away from making demands that they thought were adequate in relation the their professional core tasks.

The absence of professional recognition from the municipal employer was evident. Since the preschool teachers needed professional recognition, they experienced the collaborative nature of this study of great value as it conferred legitimacy on their professional development. Despite resistance from their municipal employer, there emerged meaningful pedagogical changes over time, which emphasised the significance of organisational change from the bottom up. Collective actions began to take root in a shared value system that could only be created by way of shared reflections on actions over time. The design of the project - to collaborate with an outside ally (cf table 1) - was decisive in regard to creating space for reflection and collective actions, as several of the above examples illustrate.

\section{Discussion}

This study shows the importance for practitioners to have an ally to mirror themselves and their actions. An outsider had everything to do with the significance of recognition and the possibilities of creating dominant forms of knowledge as discussed by Smith (1990). The municipal employer did not give the preschool teachers the response they thought they needed as an endorsement of their professional practices. Especially feminist action research's ethical and action-oriented approach is unlikely to leave practitioners to fend for themselves in gendered professions and organisations, in situations where recognition is long in coming. Instead, gendered experiences are considered meaningful as long as they can be translated into new actions. Feminist action research goes beyond making statements on how things are and what a certain group of practitioners are like. This corresponds well with the feminist pragmatist thought that served as theoretical and philosophical underpinning of this study (Minnich 2005, Seigfried 2002). It also resonates well with Biesta \& Burbules' (2003) interpretation of Dewey's view on educational research and its purpose in and for society:

One of the most significant and characteristic implications of Dewey's transactional approach is that educational research will not result in rules for educational action. Educational research can only ever show us what has been possible in a specific situation of something called a 'representative sample' - but it can never tell us once and for all what to do. (Biesta \& Burbules 2003, p. 110)

Despite strong organisational resistance from their own employer, the preschool teachers succeeded in interpreting educational policy by creating time and space for reflection. The emancipatory and democratic implications of this type of organisational learning and professional development can be summarised as the transformative processes that are a prerequisite to organisational development and change in a way capable professional practitioners within an organisation deem fit.

Choice points, regardless of how harmlessly small they may seem, can lead to significant organisational changes. They can also have meanings in terms of empowerment, as the empirical examples in this article illustrate. Most importantly for feminist action research, 
however, choice points remind us of the role we have as researchers, the ethical responsibility we have when juggling all the collective and individual processes in a project, and of the preparedness we need at all times during an action research project in order to be able to cope with organisational power games and professional dilemmas that more likely than not will emerge once we engage whole-heartedly in an action research project. 


\section{References}

Berge, B-M. \& H. Ve 2000. Action Research for Gender Equity. Maidenhead: Open University Press.

Biesta, G. 2006. Bortom lärandet. Demokratisk utbildning för en mänsklig framtid. Lund: Studentlitteratur. (English Translation: Beyond Learning. Democratic Education for a Human Future).

Biesta, G. and N. Burbules 2003. Pragmatism and Educational Research. Lanham, USA: Rowman \& Littlefield Publishers, Inc.

Brydon-Miller, M. 2008. Ethics and Action Research: Deepening our Commitment to Principles of Social Justice and Redefining Systems of Democratic Practice. I: P. Reason and H. Bradbury 2008. The Sage Handbook of Action Research. Participative Inquiry and Practice. Los Angeles, London, New Delhi, Singapore: Sage Publications

Campbell, A. and S. Groundwater-Smith 2007. An Ethical Approach to Practitioner Research. London and New York: Routledge

Clandinin, J. (ed.) 2007. Handbook of Narrative Inquiry. Mapping a Methodology. Thousand Oaks, London, New Delhi: Sage Publications

Dahle, R. 2008. Profesjon och kjønn. I: Molander, A. \& L.I. Terum. Profesjonsstudier. Oslo: Universitetsforlaget. (Translation of chapter: Profession and Gender, p. 216 - 232. Translation of book title: The Study of the Professions).

Davies, C. 1996. The Sociology of Professions and The Professions of Gender. Sociology 30, no. 4, (November): 661-678

Etzioni, A. 1969. Women and Bureaucracy in the Semi-Professions. In: The SemiProfessions and Their Organization. Teachers, Nurses, Social Workers (ed. Etzioni, Amitai.) New York: The Free Press

Fröbel, F. 1826. Die Menschenerziehung, die Erziehungs-, Unterrichts- und Lehrkunst. Keilhau: Allgemeine deutschen Erziehungsanstalt zu Keilhau; dargestellt von dem Stifter, Begründer und Vorsteher derselben, Friedrich Wilhelm August Fröbel. http://www.froebelverein-keilhau.de/downloads/diemenschenerziehung.pdf (downloaded 9th April 2011, Translation (abbreviation): The Education of Mankind, the art of education and teaching illustrated by the founding father and director of the Common German Educational Institution in Keilhau: Friedrich Wilhelm August Fröbel)

Griffiths, M. 1998. Educational Research for Social Justice. Getting off the fence. Buckingham: Open University Press

Herr, K. and G. Anderson 2005. The Action Research Dissertation. A guide for students and faculty. Thousand Oaks, London, New Delhi: Sage Publications

Läroplanen för förskolor, Lpfö 98. 1998. National Curriuculum for Preschools in Sweden. Stockholm: Swedish Ministry of Education and Research

Maguire, P. 2005. Introduction. In: K. Herr and G. Anderson 2005. The Action Research Dissertation. A guide for students and faculty. Thousand Oaks, London, New Delhi: Sage Publications

Mazur, A. 2006. Theorizing Feminist Policy. New York: Oxford University Press

McNiff, J. and J. Whitehead 2000. Action Research in Organisations. Abingdon: Routledge

Minnich, E.K. 2002. Philosophy, Education, and the American Tradition of Aspirational Democracy. I: C. Seigfried, ed. 2002. Feminist Interpretations of John Dewey. Pennsylvania: Pennsylvania State University Press

Minnich, E.K. 2005. Transforming Knowledge. Philadelphia: Temple University Press 
Myrdal, A. and G. Myrdal. 1934. Kris I befolkningsfrågan. Stockholm Bonniers. (English title: Crisis in the population question.)

Persson, S. and I. Tallberg-Broman 2002. "Det är ju ett annat jobb" Förskollärare, grundskollärare och lärarstuderande om professionell identitet i konflikt och förändring Pedagogisk Forskning $i$ Sverige 7, $\mathrm{nr}$ 4: 257-278. Institutionen för pedagogik och didaktik, Göteborgs universitet, ISSN 1401-6788, URI (English title of article: "This is, after all, another kind of job." Preschool teachers, primary school teachers and teacher students on conflicting and changing professional identities.)

Pincus, I. 2002. The Politics of Gender Equality Policy. Implementation and Nonimplementation in three Swedish Municipalities. Örebro: Örebro Studies in Political Science

Quennerstedt, A. 2006. Kommunen - en part $i$ utbildningspolitiken? Örebro: Örebro Studies in Education 14 (Title in English: The municipality (the local authority) as a participant in Swedish educational policy?)

Reid, C. 2004. Advancing women's social justice agendas: A feminist action research framework. International Journal of Qualitative Methods 3(3) Article 1. https://ejournals.library.ualberta.ca/index.php/IJQM/article/viewFile/4462/3595

Seigfried, C.S. (ed) 2002. Feminist Interpretations of John Dewey. Pennsylvania: Pennsylvania State University Press

Smith, D. 1990. The Conceptual Practices of Power. A feminist sociology of knowledge. Boston: Northeastern University Press

Tallberg-Broman, I. 1991. När arbetet var lönen. En kvinnohistorisk studie av barnträdgårdsledarinnan som folkuppfostrare. Malmö: Almqvist \& Wiksell International (Translation of book title into English: When work itself was considered remuneration. $A$ study of the history of nursery school head mistresses as educators of the people).

Vallberg-Roth, A-C. 2001. Läroplaner för de yngre barnen. Utvecklingen från 1800-talets mitt till idag. Pedagogisk Forskning i Sverige 2001 årg 6 nr 4 s 241-269 issn 1401-6788 (English translation of article: National curriculum for young children. From mid- $19^{\text {th }}$ century to today).

Witz, A. 1992. Professions and Patriarchy. London: The International Library of Sociology 


\section{Table 1}

My varied positions as researcher and an action research study's expected contributions

\begin{tabular}{|l|l|l|}
\hline \multicolumn{2}{|l|}{ Researcher's position } & Contributions \\
\hline 1. & $\begin{array}{l}\text { Insider } \\
\text { (researcher studies own } \\
\text { self/practice) }\end{array}$ & $\begin{array}{l}\text { Knowledge base, } \\
\text { improved/critiqued practice, } \\
\text { self/professional } \\
\text { transformation }\end{array}$ \\
\hline 2. & $\begin{array}{l}\text { Insider in collaboration } \\
\text { with others }\end{array}$ & $\begin{array}{l}\text { Knowledge base, } \\
\text { improved/critiqued practice, } \\
\text { professional and } \\
\text { organisational change }\end{array}$ \\
\hline 3. & $\begin{array}{l}\text { Insider(s) in } \\
\text { collaboration with } \\
\text { outsider(s) }\end{array}$ & $\begin{array}{l}\text { Knowledge base } \\
\text { Improved/critiqued practice, } \\
\text { Professional and } \\
\text { organisational change }\end{array}$ \\
\hline 4. & $\begin{array}{l}\text { Reciprocal collaboration } \\
\text { (insider-outsider teams) }\end{array}$ & $\begin{array}{l}\text { Knowledge base, } \\
\text { Improved/critiqued practice, } \\
\text { Professional and } \\
\text { organisational change }\end{array}$ \\
\hline 5. & $\begin{array}{l}\text { Outsider(s) in } \\
\text { collaboration with } \\
\text { insider(s) }\end{array}$ & $\begin{array}{l}\text { Knowledge base, } \\
\text { Improved/critiqued practice, } \\
\text { Organisational and } \\
\text { professional change }\end{array}$ \\
\hline 6. & $\begin{array}{l}\text { Outsider(s) studies } \\
\text { insider(s) }\end{array}$ & \begin{tabular}{l} 
Knowledge base \\
\hline
\end{tabular}
\end{tabular}

Note: Researcher's position scale, Insider 1 - Outsider 6.

Source: original table by Herr \& Anderson, 2005, p. 31, new table by author 